\title{
Pengaruh Pemangkasan Cabang dan Mikoriza terhadap Produksi dan Mutu Benih Mentimun (Cucumis Sativus L.)
}

\author{
ANWI APRILIANA ${ }^{1}$, ENDANG PUDJIHARTATI ${ }^{2 *)}$, DAN HARMASTINI SUKIMAN ${ }^{3}$ \\ ${ }^{1}$ Program Studi Agroteknologi, Fakultas Pertanian dan Bisnis, Universitas Kristen Satya \\ Wacana Salatiga \\ ${ }^{2}$ Fakultas Pertanian dan Bisnis, Universitas Kristen Satya Wacana Salatiga \\ ${ }^{3}$ Pusat Penelitian Bioteknologi Lembaga Ilmu Pengetahuan Indonesia (LIPI) \\ J1. Diponegoro 52-60, Salatiga 50711 Jawa Tengah \\ ${ }^{*}$ E-mail: endang.hartati@uksw.edu
}

\begin{abstract}
The Effect of Branch Pruning and Mycorrhiza on Production and Seed Quality of Cucumis sativus L. The purpose of this study was to obtain the best branch pruning, with or without mycorrhiza application, in order to increase the production and quality of cucumber seeds. Pruning the branch at the beginning of cucumber growth is expected to delay fruit formation and support good vegetative growth. This research was carried out in the PT. Primasid Andalan Utama seed production area in Kalibeji Village, Tuntang District, Semarang Regency, Seed Technology Laboratory and Plant Physiology Laboratory, Faculty of Agriculture and Business, Satya Wacana Christian University. This study was conducted by the split-plot randomized complete block design with 2 factors. The main plot consists of 2 levels, namely control/without mycorrhiza $\left(\mathrm{M}_{0}\right)$ and mycorrhiza application $\left(\mathrm{M}_{1}\right)$. Pruning the branches as the subplots consist of 4 levels, were pruning to the second, third, fourth and fifth branches of the cucumber plant $\left(\mathrm{P}_{1}, \mathrm{P}_{2}, \mathrm{P}_{3}\right.$ and $\left.\mathrm{P}_{4}\right)$. DMRT was used to differentiate the significance of the treatment. The results showed that mycorrhiza application increased the percentage of root infections. The pruning to the fifth branch $\left(\mathrm{P}_{4}\right)$ is the best; in control without mycorrhiza $\left(\mathrm{M}_{0} \mathrm{P}_{4}\right)$ increased for the number of fruits, the seed weight per plant, and the germination simultaneously; whereas in mycorrhiza application $\left(\mathrm{M}_{1} \mathrm{P}_{4}\right)$ increased the number of fruits and the seed weight per plant. It is also observed that the pruning to the second branch $\left(\mathrm{P}_{1}\right)$ increased the weight of 1000 grains, the speed of germination and the simultaneous of germination; both with and without mycorrhiza application.
\end{abstract}

Keywords: branch pruning, mycorrhiza, production, seed quality, cucumis sativus L

\section{PENDAHULUAN}

Produktivitas mentimun di Indonesia masih rendah. Pada tahun 2012 sampai 2016 produktivitas mentimun menurun berturut turut 9,97 ton/ha (2012), 9,97 ton/ha (2013), 9,84 ton/ha (2014), 10,27 ton/ha (2015) dan 
ANWI APRILIANA. et al. Pengaruh Pemangkasan Cabang dan Mikoriza terhadap Produksi...

10,19 ton/ha (2016) (BPS, 2015 dan BPS, kurang maksimal sehingga benih yang 2017). Padahal produktifitas beberapa dihasilkan sedikit. Semakin tinggi cabang, Varietas mentimun yang dikeluarkan Balai semakin sedikit asimilat yang didapat untuk Penelitian Tanaman Sayur (Balitsa) seperti pertumbuhan buah/biji, karena sudah dipakai varietas Saturnus, Mars dan Pluto mencapai 23-30 ton/ha (Balitsa, 2018). Hal ini untuk buah pada cabang-cabang bawah. kemungkinan budidaya mentimun yang dilakukan masih kurang intensif, termasuk penggunaan benih mentimun bermutu rendah. Salah satu cara untuk meningkatkan produktivitas mentimun adalah menggunakan benih hibrida.

Menurut Dewani (2000), untuk meningkatkan produksi tanaman kacang hijau dapat dilakukan dengan cara memanipulasi pertumbuhan yaitu dengan pemangkasan, sehingga membatasi pertumbuhan vegetatif tanaman. Jika pertumbuhan vegetatif tidak diatur sedangkan faktor lingkungan mendukung, maka tanaman akan terus melakukan pertumbuhan vegetatif terus menerus, sehingga pertumbuhan generatif bisa terhambat. Selain itu cahaya matahari yang masuk ke tanaman lebih banyak, sehingga akan merangsang pembentukan bunga.

Tanaman mentimun sendiri memiliki cabang lateral pada setiap ruasnya. Setiap cabang terdapat bunga betina. Jika semua cabang yang tumbuh dipelihara, buah-buah pada cabang yang terbentuk berikutnya Pemangkasan cabang pada mentimun mengikut sertakan juga bunganya, karena bunga tanaman mentimun tumbuh pada ketiak daun dan pada cabang lateral. Perlu dikaji lebih lanjut tentang pemangkasan cabang yang tepat untuk menghasilkan benih dengan kualitas dan kuantitas tinggi.

Selain pemangkasan cabang, untuk meningkatkan kuantitas dan kualitas benih mentimun adalah meningkatkan serapan hara, khususnya fosfor. Asam fitat (myoinositol hexakisphosphate) adalah senyawa sekunder dalam tanaman yang berupa simpanan utama dari fosfor dalam biji-bijian, sebanyak 60-80 fosfor yang ada dalam organ-organ benih (Reddy dan Sathe, 2001).

Fluktuasi lingkungan, lokasi, berbagai aplikasi pupuk, dan tahun di mana kultivar atau varietas ditanam mempengaruhi kandungan fitat biji. Pemberian unsur fosfat dalam jumlah yang memadai dapat meningkatkan mutu benih yang meliputi potensi perkecambahan dan vigor bibit (Mugnisjah dan Setiawan, 1990).

Namun ketersediaan $\mathrm{P}$ yang dapat diserap tanaman umumnya rendah. Menurut 
penelitian Sari dkk. (2017), P tersedia pada tanah latosol tergolong rendah, yaitu sebesar 6,99 ppm P. Menurut Indranada (1986) dan Nyakpa dkk. (1988), fosfor dalam larutan tanah rendah karena dipengaruhi oleh beberapa hal, antara lain (1) efisiensi pupuk $\mathrm{P}$ relatif sangat rendah, dari $\mathrm{P}$ yang diberikan hanya 5-25\% yang dapat diserap oleh tanaman, (2) fiksasi $\mathrm{P}$ oleh ion-ion $\mathrm{Fe}, \mathrm{Al}$ dan $\mathrm{Ca}$, (3) tingkat kehilangan $\mathrm{P}$ (terangkut tanaman, tercuci, erosi).

Adapun usaha yang dapat dilakukan untuk mengefisienkan penggunaan pupuk fosfor adalah dengan pemanfaatan fungi mikoriza arbuskular (FMA). Hidayat dkk. (2016) menyatakan bahwa mikoriza yang berasosiasi dengan akar tanaman dapat meningkatkan penyerapan unsur hara terutama fosfat, hal ini disebabkan pada akar tanaman yang terinfeksi mikoriza dapat meningkatkan aktivitas fosfatase. Enzim ini berfungsi untuk mengkatalis hidrolisis kompleks fosfor tidak larut dalam tanah menjadi tersedia.

Berdasarkan latar belakang tersebut maka penulis terdorong untuk mencoba meneliti tentang pengaruh pemangkasan cabang dan pemberian mikoriza terhadap peningkatan produksi dan mutu benih mentimun (cucumis sativus L.). Adapun tujuan dari penelitian ini adalah mengetahui pengaruh pemangkasan cabang terhadap produksi dan mutu benih mentimun dengan pemberian mikoriza.

\section{BAHAN DAN METODE}

Percobaan dilaksanakan di lahan produksi benih PT Primasid Andalan Utama yang berada di Desa Kalibeji, Kecamatan Tuntang, Kabupaten Semarang, Jawa Tengah, Laboratorium Teknologi Benih dan Laboratorium Fisiologi Tumbuhan, Fakultas Pertanian dan Bisnis, Universitas Kristen Satya Wacana pada bulan April-Juni 2018.

Penelitian ini menggunakan Rancangan perlakuan Petak Terpisah (Split Plot Design) dan rancangan lingkungan Rancangan Acak Kelompok (RAK), dengan petak utama adalah mikoriza (M) yang terdiri dari 2 taraf yaitu: tanpa pemberian mikoriza (M0) dan pemberian mikoriza (M1). Sedangkan anak petak adalah pemangkasan cabang yang terdiri dari 4 taraf, yaitu : pemangkasan sampai cabang ke 2 (P1), pemangkasan sampai cabang ke 3 (P2), pemangkasan sampai cabang ke 4 (P3) dan pemangkasan sampai cabang ke 5 (P4). Masing-masing perlakuan diulang empat kali.

Penelitian ini dilakukan dalam rangka produksi benih hibrida varietas Barokah, dengan tetua betina Kode K790 dan tetua jantan dengan kode K971. Tanaman 
ANWI APRILIANA. et al. Pengaruh Pemangkasan Cabang dan Mikoriza terhadap Produksi...

mentimun ditumbuhkan dalam polibeg dan media tanam tanah: pupuk kandang, yaitu 2:1. Mikoriza yang digunakan adalah Pupuk BIOVAM dari LIPI, diberikan 2g/lubang tanam pada saat pindah tanam bibit mentimun. Pemupukan susulan diberikan seminggu sekali, dengan sistem kocor. Pupuk NPK (16:16:16) diberikan pada saat pertumbuhan vegetatif hingga panen. Kemudian pada saat tanaman mulai berbunga, juga diberikan pupuk monokalium phospat dan $\mathrm{KCl}$ diberikan secara berselangseling.

Parameter utama yang diamati, antara lain persentase infeksi akar pada 42 HST dan 64 HST, serapan fosfor, kandungan asam fitat benih, bobot benih per buah, bobot benih per tanaman, jumlah benih per buah, bobot 1000 butir, daya Berkecambah (DB), Kecepatan Tumbuh (KCT), Keserempakan Tumbuh (KST). Sedangkan parameter penunjang analisis tanah sebelum percobaan. Data hasil pengamatan dianalisis menggunakan uji F 5\%. Apabila perlakuan menunjukkan pengaruh nyata, kemudian dilanjutkan dengan uji DMRT dengan taraf $5 \%$.

\section{HASIL DAN PEMBAHASAN}

\section{Analisis Tanah Sebelum Percobaan}

Hasil analisis tanah sebelum percobaan dari laboratorium Kimia BPTP Jateng, menunjukkan bahwa $\mathrm{PH} \mathrm{H}_{2} \mathrm{O}$ tanah 6,81 (netral), C-organik 2,67\% (sangat rendah), $\mathrm{N}$ Kjeldahl 0,31\% (sangat rendah), $\mathrm{P}$ tersedia 502,04 ppm (sangat tinggi), K2O 208,96 $\mathrm{mg} / 100 \mathrm{~g}$ (sangat tinggi). Penilaian sifat kimia tanah ini berdasarkan kriteria dari Balai Penelitian Tanah (Eviati dan Sulaeman, 2009).

\section{Persentase infeksi mikoriza}

Hasil penelitian diamati bahwa akar tanaman mentimun tanpa diberi mikoriza (M0) pada 42 hst sudah terdapat infeksi mikoriza, sebesar $6,25 \%$. Hal ini diduga pada tanah yang digunakan dalam penelitian ini sudah mengandung spora mikoriza. Menurut Siddiqui dkk. (2008), mikoriza berasal dari tanah atau disebut dengan mikoriza indigenous dan berkoloni di dekat perakaran tanaman. Menurut penelitian Yusrinawati dkk, 2017, perlakuan kontrol (tanpa diberi mikoriza indigenous) pada bawang merah memiliki persentase infeksi akar sebesar 30$40 \%$.

Hasil analisis sidik ragam (Tabel 1) menunjukkan bahwa perlakuan mikoriza meningkatkan persentase infeksi mikoriza 
pada 42 HST secara nyata. Pemberian mikoriza (M1) memiliki infeksi akar lebih tinggi $(16,25 \%)$ dibanding tanpa pemberian mikoriza (M0). Pada 64 HST, persentase infeksi mikoriza pada tanaman mentimun yang diberi mikoriza (M1 23,13\%) juga tetap lebih tinggi dibanding tanaman yang tidak diberi mikoriza (M0 13,33\%).

Pada Tabel 1, persentase infeksi mikoriza pada 42 dan 64 HST berkisar 525\%. Menurut Setiadi (1994), infeksi mikoriza 6-25\% tergolong rendah. Hal ini terjadi diduga karena tingginya kandungan fosfat tersedia pada tanah. Menurut Mukerji (2013), efek mikoriza umumnya menurun dengan peningkatan fosfat tersedia dalam tanah. Peningkatan fosfat terlarut memodifikasi perkembangan hifa eksternal dengan baik sebelum mempengaruhi kemampuan jamur untuk menjajah jaringan akar internal. Demikian juga jumlah miselium ekternal yang diproduksi menurun pada tingkat fosfat tinggi.

Tabel 1. Pengaruh pemangkasan cabang dan pemberian mikoriza terhadap presentase infeksi akar 42 HST dan 64 HST

\begin{tabular}{lccc}
\hline & Perlakuan & $\begin{array}{c}\text { Persentase infeksi } \\
\text { mikoriza 42 HST (\%) }\end{array}$ & $\begin{array}{c}\text { Persentase infeksi } \\
\text { mikoriza 64 HST (\%) }\end{array}$ \\
\hline \hline Pemangkasan & & & \\
M0 & P1 & $5,00 \mathrm{a}$ & $12,50 \mathrm{a}$ \\
& P2 & $7,50 \mathrm{a}$ & $12,50 \mathrm{a}$ \\
& P3 & $5,00 \mathrm{a}$ & $15,00 \mathrm{a}$ \\
P4 & $7,50 \mathrm{a}$ & $12,50 \mathrm{a}$ \\
\hline M1 & P1 & $15,00 \mathrm{a}$ & $22,50 \mathrm{a}$ \\
& P2 & $17,50 \mathrm{a}$ & $22,50 \mathrm{a}$ \\
& P3 & $17,50 \mathrm{a}$ & $22,50 \mathrm{a}$ \\
Mikoriza & P4 & $15,00 \mathrm{a}$ & $25,00 \mathrm{a}$ \\
M0 & & & \\
M1 & & $6,25 \mathrm{~b}$ & $13,13 \mathrm{~b}$ \\
CV (\%) & & $16,25 \mathrm{a}$ & $23,13 \mathrm{a}$ \\
\hline Keteangan: Nilai yang & 14,56 & 18,68 \\
\hline
\end{tabular}

Keterangan: Nilai yang diikuti oleh huruf yang sama menunjukkan tidak berbeda nyata pada taraf 5\% menurut uji DMRT. 
ANWI APRILIANA. et al. Pengaruh Pemangkasan Cabang dan Mikoriza terhadap Produksi...

Tabel 2. Pengaruh pemangkasan cabang dan pemberian mikoriza terhadap serapan hara $\mathrm{P}$ tanaman dan kandungan asam fitat benih

\begin{tabular}{|c|c|c|c|}
\hline \multicolumn{2}{|c|}{ Perlakuan } & $\begin{array}{c}\text { Serapan Hara }(\mathrm{mg} / \mathrm{g} \\
\text { tanaman kering) }\end{array}$ & $\begin{array}{l}\text { Asam Fitat Benih } \\
\text { (mg/g benih) }\end{array}$ \\
\hline \multicolumn{4}{|c|}{ Pemangkasan } \\
\hline \multirow[t]{5}{*}{ M0 } & P1 & 012 & $\begin{array}{c}1,85 \mathrm{a} \\
\mathrm{B}\end{array}$ \\
\hline & P2 & & $1,94 \mathrm{a}$ \\
\hline & 12 & $0,15 \mathrm{a}$ & B \\
\hline & P3 & $0,16 \mathrm{a}$ & $\begin{array}{c}1,84 \mathrm{a} \\
\mathrm{B}\end{array}$ \\
\hline & P4 & $0.15 \mathrm{a}$ & $\begin{array}{c}1,97 \mathrm{a} \\
\mathrm{B}\end{array}$ \\
\hline \multirow{7}{*}{ M1 } & D1 & & $2,26 \mathrm{a}$ \\
\hline & P1 & $0,14 \mathrm{a}$ & A \\
\hline & P2 & & $1,78 \mathrm{~b}$ \\
\hline & & $0,10 \mathrm{a}$ & B \\
\hline & P3 & $0,17 \mathrm{a}$ & BC \\
\hline & P4 & & $1,44 \mathrm{c}$ \\
\hline & & $0,16 \mathrm{a}$ & C \\
\hline \multicolumn{4}{|l|}{ Mikoriza } \\
\hline M0 & & $0,14 \mathrm{a}$ & $1,90 \mathrm{a}$ \\
\hline M1 & & $0,16 \mathrm{a}$ & $1,80 \mathrm{a}$ \\
\hline $\mathrm{CV}(\%)$ & & 13,26 & 6,27 \\
\hline
\end{tabular}

\section{Serapan Hara P Tanaman}

Pada Tabel 2 menunjukkan bahwa pemberian mikoriza (M1) meningkatkan serapan hara P. Tingkat serapan hara $\mathrm{P}$ tanaman mentimun yang diberi mikoriza (M1) tidak berbeda nyata dibanding tanpa pemberian mikoriza (M0). Diduga kandungan $\mathrm{P}$ tersedia dalam tanah yang digunakan dalam penelitian ini tergolong sangat tinggi sehingga pemberian mikoriza tidak memperlihatkan peningkatan mikoriza. serapan hara $\mathrm{P}$.
Hasil penelitian Guntoro dkk. (2007), kandungan fosfor tajuk tanaman tidak berbeda nyata pada perlakuan $0 \mathrm{~g} /$ pot sampai $200 \mathrm{~g} /$ pot pupuk hayati mikoriza. Hal ini diduga karena tingginya kandungan fosfor pada tanah. Menurut Mukerji (2013), efek mikoriza umumnya menurun dengan peningkatan fosfor tersedia dalam tanah. Efek pertama dari tingkat fosfor tinggi adalah pengurangan fase penyerapan dari sistem 
Demikian juga pada perlakuan pemangkasan baik tanpa pemberian mikoriza (M0) maupun pemberian mikoriza (M1) tidak berbeda nyata. Hal ini diduga karena persentase infeksi akar tidak berbeda nyata (Tabel 1) sehingga penyerapan fosfor tidak berbeda nyata.

\section{Asam Fitat Benih}

Pada tabel 2 menunjukkan bahwa perlakuan mikoriza baik M0 maupun M1 tidak berbeda nyata pada tolok ukur kandungan asam fitat benih. Hal ini terjadi karena serapan fosfor tanaman juga tidak berbeda nyata. Selain itu diduga mikoriza kurang efektif dalam penyerapan hara fosfor. Menurut Hidayat (2016), hifa ekternal mikoriza membantu memperluas daerah penyerapan akar dengan semakin luasnya daerah penyerapan akar maka semakin besar juga daya serap akarnya. Pada analisis tanah awal, kandungan posfor pada media tanam sangat tinggi. Mikoriza kurang efektif bekerja pada tanah dengan posfor tinggi.

Pada taraf tanpa pemberian mikoriza, perlakuan pemangkasan tidak berbeda nyata. Sedangkan pada taraf pemberian mikoriza berbeda nyata, pemangkasan cabang sampai ruas ke 2 (P1) dapat meningkatkan kandungan asam fitat benih. Hal ini bisa terjadi karena buah pada cabang bawah lebih dekat dengan akar, sehingga akan lebih banyak menyerap nutrisi terkhusus fosfor. Menurut Zamski (1996), benih adalah sink yang kuat. dimana membutuhkan asimilat yang sangat tinggi. Pada perlakuan pemangkasan lainnya, semakin tinggi pemangkasan, semakin rendah kandungan asam fitatnya. Hal ini diduga berhubungan dengan letak buahnya. Semakin banyak pemangkasan, semakin tinggi letak buahnya.

Interaksi antara mikoriza dan pemangkasan pada parameter kandungan asam fitat menunjukkan bahwa perlakuan P1M1 memiliki kandungan asam fitat tertinggi, yaitu sebesar 2,26 mg/g. Menurut Manske (1988) dalam Sastrahidayat (2010), mikoriza meningkatkan kemampuan tanaman untuk menyerap fosfor yang terikat dalam tanah dan fosfat dari pupuk. Selain itu biji/benih adalah sink yangsangat kuat, jika buah tumbuh pada cabang bawah, maka fosfor dan nutrisi lainnya akan terserap pada buah cabang terbawah, sehingga buah pada cabang-cabang atas kekurangan nutrisi. 
ANWI APRILIANA. et al. Pengaruh Pemangkasan Cabang dan Mikoriza terhadap Produksi...

Tabel 3. Pengaruh pemangkasan cabang dan pemberian mikoriza terhadap kuantitas benih mentimun

\begin{tabular}{|c|c|c|c|c|c|c|}
\hline \multicolumn{2}{|c|}{ Perlakuan } & \multirow[t]{2}{*}{$\begin{array}{l}\text { Jumlah } \\
\text { Buah }\end{array}$} & \multirow[t]{2}{*}{$\begin{array}{l}\text { Bobot } 1000 \\
\text { butir }(\mathrm{g})\end{array}$} & \multirow[t]{2}{*}{$\begin{array}{l}\text { Jumlah benih } \\
\text { bernas }\end{array}$} & \multirow[t]{2}{*}{$\begin{array}{l}\text { Bobot benih } \\
\text { per buah }(\mathrm{g})\end{array}$} & \multirow[t]{2}{*}{$\begin{array}{l}\text { Bobot benih per } \\
\text { tanaman }(\mathrm{g})\end{array}$} \\
\hline \multirow{5}{*}{$\begin{array}{l}\text { Pemangk } \\
\text { M0 }\end{array}$} & & & & & & \\
\hline & P1 & $1,67 \mathrm{~b}$ & $34,34 \mathrm{a}$ & $172,54 \mathrm{a}$ & $5,84 \mathrm{a}$ & $9,43 \mathrm{~b}$ \\
\hline & P2 & $1,89 \mathrm{ab}$ & $33,41 \mathrm{~b}$ & $160,96 \mathrm{a}$ & $5,38 \mathrm{a}$ & $10,23 a b$ \\
\hline & P3 & $2,02 \mathrm{ab}$ & $33,13 \mathrm{~b}$ & $165,09 \mathrm{a}$ & $5,41 \mathrm{a}$ & $9,59 \mathrm{~b}$ \\
\hline & P4 & $2,28 \mathrm{a}$ & $33,25 \mathrm{~b}$ & $161,35 \mathrm{a}$ & $5,42 \mathrm{a}$ & $12,31 \mathrm{a}$ \\
\hline \multirow[t]{4}{*}{ M1 } & P1 & $1,81 \mathrm{~b}$ & $34,17 \mathrm{a}$ & $143,02 \mathrm{a}$ & $4,92 \mathrm{a}$ & $9,13 \mathrm{~b}$ \\
\hline & P2 & $1,90 \mathrm{~b}$ & $33,67 \mathrm{ab}$ & $142,28 \mathrm{a}$ & $4,91 \mathrm{a}$ & $9,38 \mathrm{~b}$ \\
\hline & P3 & $2,00 \mathrm{ab}$ & $33,64 \mathrm{ab}$ & $131,53 \mathrm{a}$ & $4,46 \mathrm{a}$ & $8,74 \mathrm{~b}$ \\
\hline & P4 & $2,19 \mathrm{a}$ & $33,15 \mathrm{~b}$ & $151,143 \mathrm{a}$ & $4,89 \mathrm{a}$ & $10,41 \mathrm{a}$ \\
\hline \multicolumn{7}{|c|}{ Mikoriza } \\
\hline M0 & & $1,97 \mathrm{a}$ & $33,53 \mathrm{a}$ & $164,99 \mathrm{a}$ & $5,51 \mathrm{a}$ & 10,39 a \\
\hline M1 & & $1,96 \mathrm{a}$ & $33,66 \mathrm{a}$ & $142,00 \mathrm{~b}$ & $4,79 \mathrm{~b}$ & $9,41 \mathrm{a}$ \\
\hline CV (\%) & & 12,41 & 1,23 & 8,54 & 9,63 & 16,11 \\
\hline
\end{tabular}

Keterangan: Nilai yang diikuti oleh huruf yang sama (huruf kecil dan huruf besar arah horisontal) menunjukkan tidak berbeda nyata pada taraf 5\% menurut uji DMRT

\section{Jumlah Buah}

Pada perlakuan tanpa pemberian mikoriza (M0) dan pemberian mikoriza (M1) tidak berbeda nyata pada tolok ukur jumlah buah. Hal ini diduga mikoriza yang diberikan tidak bisa langsung berpengaruh, tetapi dengan beberapa kali musim tanam atau dengan umur tanaman yang lebih panjang kemungkinan menjadi berpengaruh.

Perlakuan pemangkasan cabang berbeda nyata. Pada pemangkasan cabang tanpa pemberian mikoriza, perlakuan yang terbaik adalah $\mathrm{P} 4$, begitu pula pada perlakuan pemangkasan cabang yang diberi mikoriza. Hal ini diduga karena buah-buah pada cabang bawah yang tumbuh menyebabkan buah pada cabang atas tidak berkembang, karena nutrisi sudah di serap oleh buah pada cabang-cabang bawah. Perlakuan P1 dan P2 berbunga terlalu awal, sehingga buah yang terbentuk dan sudah berkembang menyebabkan bunga yang muncul pada cabang-cabang diatasnya tidak berkembang menjadi buah. Berbeda dengan perlakuan P3 dan P4 bunga yang tumbuh hampir serentak sehingga perkawinannya bersamaan dan pembentukan buah juga bersamaan, hal ini terlihat dari Gambar 1. 


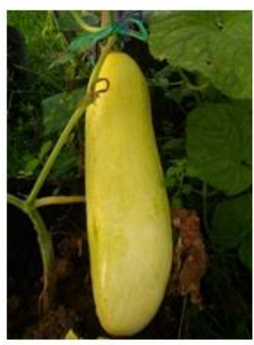

a
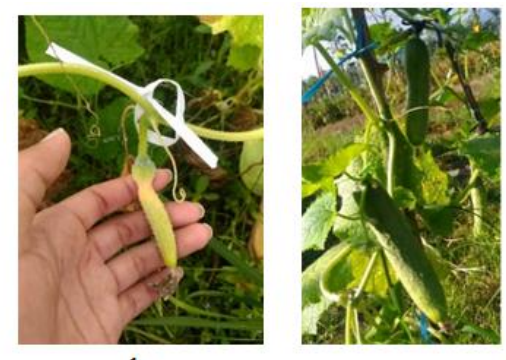

Gambar 1. (a) Buah cabang ke 3 yang sangat besar pada perlakuan P1, (b) buah cabang ke 5 yang tidak berkembang pada perlakuan P1, (c) buah pada cabang ke 6 dan 7 yang tumbuhnya seragam pada perlakuan P4. Diamati pada 53 HST atau fase perkembangan buah

\section{Bobot 1000 Butir}

Perlakuan mikoriza tidak berbeda nyata terhadap tolok ukur bobot 1000 butir. Pada taraf tanpa pemberian mikoriza dan pemberian mikoriza, perlakuan pemangkasan sampai cabang ke 2 (P1) menghasilkan bobot 1000 tertinggi. Diduga hal ini bisa terjadi karena bobot 1000 butir hubungannya dengan berat kering benih. Pada P1, buah yang terbentuk lebih awal sehingga belum ada kompetisi dengan sink buah lain. Selain itu buah pada perlakuan P1 lebih dekat dengan akar sehingga lebih banyak menyerap bahan-bahan kering.

\section{Jumlah benih bernas per buah}

Perlakuan mikoriza berbeda nyata terhadap tolok ukur jumlah benih bernas. Perlakuan M0 memiliki jumlah benih bernas lebih tinggi dibanding M1, yaitu 164,99 butir/buah. Pada taraf tanpa pemberian dan pemberian mikoriza, perlakuan pemangkasan 64 tidak berbeda nyata. Hal ini terjadi karena jumlah benih diitentukan oleh bobot benih per buah dan bobot 1000 butir.

\section{Bobot Benih per Buah}

Perlakuan mikoriza menurunkan secara nyata terhadap tolok ukur bobot benih per buah. Perlakuan M0 memiliki bobot benih per buah $(5,51 \mathrm{sg} /$ buah $)$ lebih tinggi dibanding M1 (4,79 g/buah). Hal ini diduga mikoriza indigenous lebih kompatibel dibandingkan pupuk hayati mikoriza yang diberikan.

Pada perlakuan pemangkasan cabang yang tanpa diberi maupun diberi mikoriza tidak mempengaruhi bobot kering biji. Tinggi rendahnya parameter ini tergantung dari banyak sedikitnya bahan kering yang terdapat pada biji. Selain itu menurut Kamil (1979) bahan kering ini umumnya terdiri dari tiga bahan dasar, yaitu karbohidrat, protein 
ANWI APRILIANA. et al. Pengaruh Pemangkasan Cabang dan Mikoriza terhadap Produksi...

dan lemak. Dugaan lain bobot biji tanaman kacang tanah dibanding dengan dipengaruhi oleh faktor genetik.

\section{Bobot Benih per Tanaman}

Pemberian mikoriza (M1) menurunkan secara nyata terhadap tolok ukur bobot benih per tanaman. Perlakuan M0 memiliki bobot benih per tanaman 10,39 $\mathrm{g} / \mathrm{tan}$ lebih tinggi dibanding M1, yaitu 9,41 gram/tanaman. Dalam hal ini diduga mikoriza indigenous lebih kompatibel dibandingkan pupuk hayati mikoriza yang diberikan. Hasil penelitian Nurhidayati dkk. (2011), pemberian mikoriza indigenous meningkatkan produktivitas benih per tanaman lebih tinggi.

Tabel 4. Pengaruh pemangkasan cabang dan pemberian mikoriza terhadap mutufisiologis benih mentimun

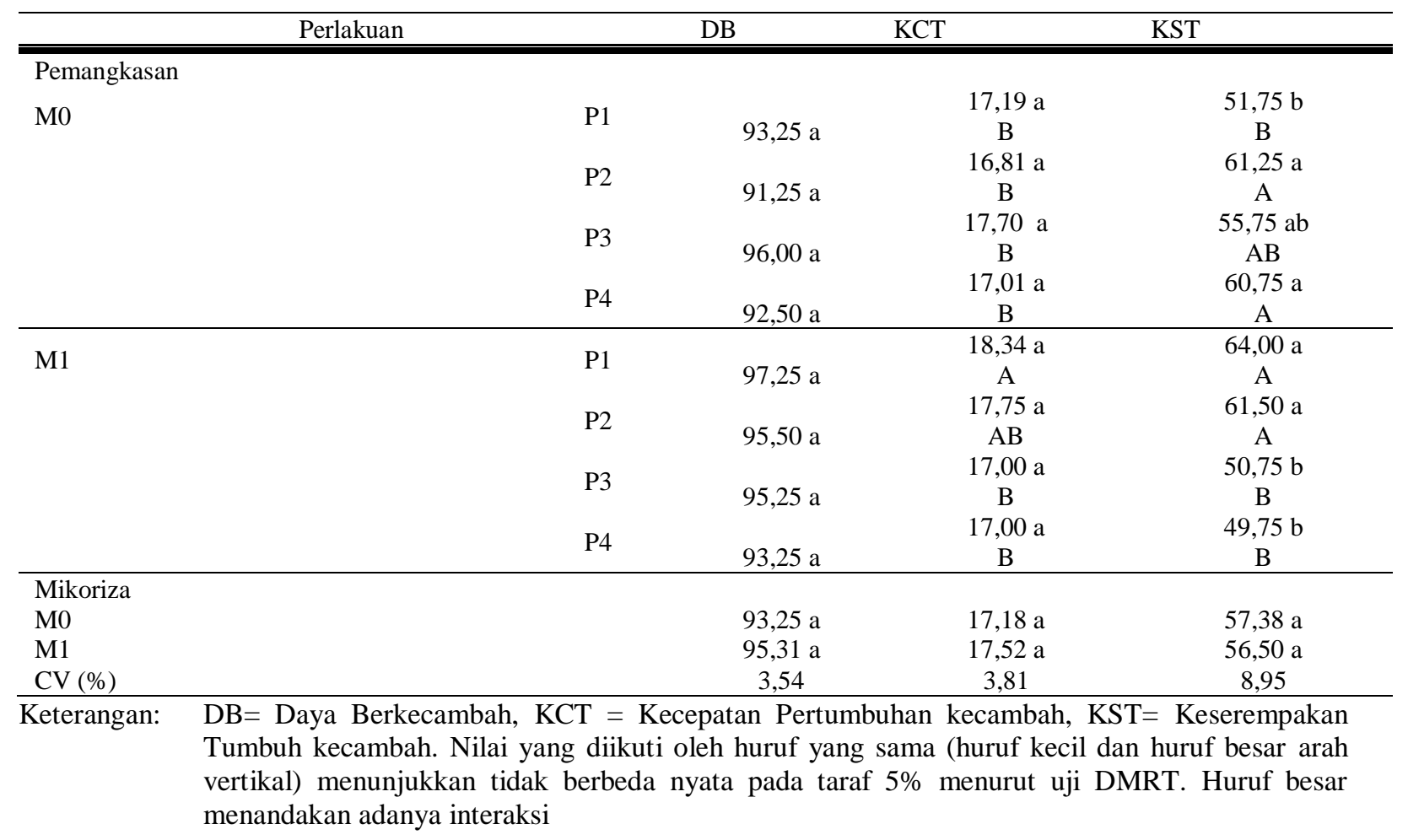




\section{Daya Berkecambah, KCTdan KST}

Perlakuan mikoriza tidak berbeda nyata terhadap tolok ukur daya berkecambah, begitupula perlakuan pemangkasan. Hal ini disebabkan karena benih diseleksi, hanya benih bernas yang dipakai sehingga daya berkecambah rata-rata sama. Menurut Sutopo (1985), faktor internal yang mempengaruhi perkecambahan antara lain: tingkat kemasakan benih, ukuran benih, berat kering benih, dormansi.

Perlakuan M0 dan M1 tidak berbeda nyata pada tolok ukur kecepatan tumbuh. Pada perlakuan pemangkasan tanpa pemberian mikoriza tidak berbeda nyata. Sedangkan pada perlakuan pemangkasan yang diberi mikoriza, perlakuan pemangkasan cabang sampai cabang ke 2 (P1) dapat meningkatkan kecepatan tumbuh benih, yaitu 18,34\%/etmal. Hal ini berkaitan dengan kandungan asam fitat benih, pada P1M1 juga tertinggi. Menurut Yudono (2012) fitin adalah cadangan posfat biji, selama proses perkecambahan, phosphatase meningkat beberapa kali lipat untuk menghidrolisis fitin. Terdapat interaksi antara perlakuan mikoriza dan pemangkasan, perlakuan terbaik pada P1M1.

Sekitar $80 \%$ fosfor di dalam benih tersimpan dalam bentuk garam myo-inositol hexakisphosphate (asam fitat). Selama proses perkecambahan, phytin dipecahkan, melepas P-organik untuk keperluan pembentukan senyawa $\mathrm{P}$ yang baru. Fosfor dalam jumlah yang memadahi dapat meningkatkan mutu benih yang meliputi potensi perkecambahan dan vigor bibit (Mugnisjah dan Setiawan, 1990; Yudono, 2012).

Pemberian mikoriza tidak memberikan pengaruh, tetapi perlakuan pemangkasan meningkatkan secara nyatapada tolok ukur KST. Pada tanaman mentimun tanpa pemberian mikoriza, perlakuan pemangkasan $\mathrm{P} 2$ dan $\mathrm{P} 4$ dapat meningkatkan keserempakan tumbuh. Pada taraf pemberian mikoriza, perlakuan pemangkasan terbaik adalah perlakuan P1 dan P2. Diduga hal ini berkaitan dengan kandungan asam fitat benih, dimana perlakuan P2M0, P4M0, P1M1, P2M1 memiliki kandungan asam fitat lebih tinggi dibanding perlakuan lainnya.

\section{SIMPULAN}

Pemberian mikoriza meningkatkan persentase infeksi akar. Pemangkasan sampai cabang ke 5 (P4) adalah yang terbaik. Pada tanaman mentimun tanpa diberi mikoriza (M0P4) meningkatkan jumlah buah, bobot benih per tanaman dan Keserempakan Tumbuh kecambah; sedangkan apabila diberi mikoriza (M1P4) 
ANWI APRILIANA. et al. Pengaruh Pemangkasan Cabang dan Mikoriza terhadap Produksi...

meningkatkan jumlah buah dan bobot benih per tanaman. Di samping itu pada pemangkasan sampai cabang ke 2 (P1), meningkatkan bobot 1000 butir, Kecepatan Tumbuh kecambah dan Keserempakan Tumbuh kecambah; baik yang tanpa diberi maupun diberi mikoriza.

Perlu dicari strain mikoriza yang lebih compatible dengan tanaman mentimun dan penelitian aplikasi mikoriza pada beberapa musim tanam berikutnya.

\section{DAFTAR PUSTAKA}

Balitsa. 2018. Varietas Mentimun. http://balitsa.litbang.pertanian.go.id/ind /index.php/varietas/mentimun. Diakses online tanggal 04 Februari 2019.

BPS. 2015. http://hortikultura.pertanian. go.id/wpcontent/uploads/2016/02/Statis tik-Produksi-2014.pdf. Diakses online tanggal 19 September 2017.

BPS. 2017. https://www.bps.go.id/ publication/2017/10/02/b14ce70bee6d5 9581e8640fe/statistik-tanaman-buahbuahan-dan-sayuran-tahunanindonesia-2016.html. Diakses online tanggal 08 Februari 2019.

Dewani, M. 2000. Pengaruh Pemangkasan terhadap Pertumbuhan dan Hasil Tanaman Kacang Hijau (Vigna rediata L.) Varietas Walet dan Wongsorejo. Jurnal Agrivita. 12(1) : 18-23.

Eviati dan Sulaeman. 2009. Petunjuk Teknis Analisis Kimia Tanah, Tanaman, Air dan Pupuk. Balai Penelitian Tanah. Bogor.

Guntoro, Dwi, B.S Purwoko, R. G.. Hurriyah. 2007. Pertumbuhan, Serapan hara dan Kualitas Turfgrass pada Beberapa Dosis Pemberian Pupuk
Hayati Mikoriza. Bul.Agron. 35 (2): 142-147.

Hidayat, N., Wignyanto, S. Sumarsih, A.I. Putri. 2016. Mikologi Industri. UB Press. Malang.

Indranada, H. K. 1986. Pengelolaan Kesuburan Tanah. PT Bina Aksara. Jakarta.

Kamil, J. 1979. Teknologi benih. Angkasa Raya. Padang.

Mugnisjah, W. Q. dan A. Setiawan. 1990. Pengantar Produksi Benih. Rajawali Press. Jakarta.

Mukerji, K.G. 2013. Concepts in Mycorrhizal Research. Kluwer Academic Publisher. Nederland.

Nurhidayati, T. , N. Jadid dan S. Meridian. 2011. Aplikasi Rhizobium dan Cendawan Mikoriza Arbuskula (CMA) terhadap Pertumbuhan Tanaman Kacang Tanah (Arachis hypogeal) di Desa Socah Kecamatan Socah Kabupaten Bangkalan Madura. Berk. Penel. Hayati. 17(77-80)

Nyakpa, M.Y, A.M. Lubis, M. A. Pulung, A. G. Amrah, A. Munawar, G. B. Hong, N. Hakim. 1988. Kesuburan Tanah. Penerbit Universitas Lampung. Lampung.

Reddy, N. R. dan S. K. Sathe. 2001. Food Phytates. CRC Press. New York.

Sari, M.N. Sudarsono dan Darmawan. 2017. Pengaruh Bahan Organik Terhadap Ketersediaan Fosfor Pada Tanah-Tanah Kaya Al dan Fe. Buletin Tanah dan Lahan. 1(1): 65-71.

Sastrahidayat, I. R. 2010. Rekayasa Pupuk Hayati Mikoriza: Dalam Meningkatkan Produksi Pertanian. UB Press. Malang.

Setiadi, Y. 1994. Mengenal Mikoriza dan Aplikasi. Pusat Antar Universitas Bioteknologi, Institut Pertanian Bogor. Bogor.

Siddiqui, Z. A., M. S. Akhtar, K. Futai. 2008. Mycorrhizae: Sustainable Agriculture and Forestry. Springer. Japan. 
Sutopo, L. 2002 Teknologi Benih. Rajawali Press. Jakarta.

Yudono, P. 2012. Perbenihan Tanaman Dasar Ilmu, Teknologi dan Pengelolaan. Gadjah Mada University Press. Yogyakarta.

Yusrinawati, I. M. Sudantha, W. Astiko. 2017. The Effort of Increasing Growth And Harvest of Local Variety Red Onion With Applications of Some Dose of Indigenous Mycorrhizal And Bioactivator Trichoderma Spp. in Dry Land. IOSR Journal of Agriculture and Veterinary Science (IOSR-JAVS). 10 (9): 42-49.

Zamski, E. 1996. Anatomical and Physiological Characteristic of Sink Cells. In E.Zamski and A. A. Schaffer (Eds.). Photoassimilate Distribution in Plantsand Crops; Source-Sink Relationships. Marcel Dekker, Inc. New York. 